\title{
Strategy to Improve Adolescent Knowledge on Sex Education: Scoping Review
}

\author{
Yustika Rahmawati Pratami ${ }^{1}$, Nurul Kurniati ${ }^{2}$, Nurul Mahmudah ${ }^{3}$ \\ 1,2,3 Universitas Aisyiyah, Ringroad Barat 63 Nogotirto Gamping Sleman 55292, Yogyakarta, \\ Indonesia \\ 1yustikarahmawati068@gmail.com*; ${ }^{2}$ nurul.kurniati@unisayogya.ac.id; ${ }^{3}$ nurulmahmudah@unisayogya.ac.id \\ * corresponding author
}

Submission date: 10 Maret 2021, Receipt date: 15 Maret 2021, Publication date: 1 April 2021

\begin{abstract}
This study aim to determine the method most instrumental in improving adolescent's knowledge about adolescent sex education and teens identify constraints in obtaining information on sex education. The methods were using stage approach to review the literature by Arskey and O'malley framework. Framework used to manage with PEOS research questions so that the search strategy uses 5 databases, viz. Pubmed, Science Direct, Wiley, Proquest And Ebsco with the identification of the relevant study according to the inclusion and exclusion criteria. The result of this study was each method has its contribution in providing information and knowledge about sex education to adolescents, however the source of the greatest role in providing sex education information mostly came from digital sources both internet and TV media.
\end{abstract}

Keywords: Adolescent, Sex Education, Digital Media,Parents, Teachers and Peers

\section{INTRODUCTION}

Comprehensive Sexuality Education (CSE) plays an important role in preparing adolescents for safe, productive lives, and understanding about HIV and AIDS, sexually transmitted infections (STIs), unwanted pregnancy, Gender-Based Violence (GBV) and Gender inequality still pose serious risks to their well-being (UNESCO, 2018). Sex education continues to focus primarily on sexual harms, morals, and sexual reproduction. Many young people approaching adulthood are encountered with conflicting, negative and confusing messages about sexuality that are often exacerbated by shyness and silence from adults, including parents and teachers. In many societies, attitudes and laws hinder public discussion of sexuality and sexual behavior, and social norms can perpetuate dangerous conditions, such as gender inequality in relation to sexual relations, family planning and the use of modern contraception (UNESCO, 2018).

Today, many of these teenagers and young adults use web and cellphone technology to find health-related information. Northwestern University found that $84 \%$ of youth searched for health information on the Web and that $34 \%$ of these people reported changes in health behavior due to web-based health information (Levitz, Wood, \& Office, 2018). Conventional learning according to Djamarahis a 
traditional learning method or it is also called the lecture method, because this method has always been used as an oral communication tool between teachers and students in the learning and learning process (Zaduqisti, 2010).

Conventional methods can also be provided by the people closest to adolescents, for example family and friends where adolescents can get information from family, teachers and peers. Sexual risk behavior among US adolescents in 2011 is a major public health concern. Nearly 800.000 young women aged 15-19 years become pregnant in the United States each year, most of them unexpected pregnancies, 1 and half of the estimated 19 million new sexually transmitted infections (STIs) diagnosed each year are between 15 and 24 years (Collins, Martino, \& Shaw, 2011).

Based on data from the Yogyakarta Special Region Health Office, the incidence of teenage pregnancy and unwanted pregnancy in 2017 aged 15-17 years 11 months was 275 people and at the age of 18-18 years 11 months there were 442 people and the number of teenage births was 725 people (DIY Health Office, February 2018). Considering the impact and risk of a lack of knowledge on adolescent sex education and the impact of learning outcomes based on wrong sources for adolescents, it can lead to negative adolescent sexual behavior, increased premarital sexual relations among adolescents, and adverse impacts on adolescent reproductive health (Mosavi, Babazadeh, Najmabadi, \& Shariati 2014).

The objectives of this scoping review are determine the method that most plays a role in increasing adolescent knowledge about adolescent sex education, identify barriers for adolescents in obtaining sex education information, recommend appropriate methods in delivering sex education to adolescents.

\section{RESEARCH METHODS}

The method used is the scoping review. Scoping review is a design to review the scope of methodology in the form of an assessment of scientific evidence and this can be done as an effort to start a study (Peterson, Pearce, Ferguson, \& Langford, 2016). The methodological framework steps in this scoping review use the Arksey and O'Malley framework in 2005, while the stages to be carried out in this scoping review consist of stage I identifying review questions, stage II identifying relevant studies, stage III article selection, stage IV map the data (data charting), and stage $\mathrm{V}$ compiles, summarizes, and reports the results (Arksey \& O'Malley, 2005).

Stage I: Identifying Scoping Review Questions: In this step the authors identify the review questions as a guide to searching literature (Arksey \& O'Malley, 2005). This step used the PEOs framework.

Table 1. framework PEOs

\begin{tabular}{ll}
\hline Population & Adolescent \\
\hline Exposure & Sex education, digital media,parents, teachers and peers \\
\hline Outcomes & Adolescent knowledge on sex education \\
\hline
\end{tabular}


Based on the identification of the scoping review question above, the question of this review is "Which method has the most role in increasing adolescent knowledge about adolescent sex education?" An inclusion criteria were articles published between 2008-2019, articles published in English, an article that discusses how digital media has an impact on sex education in adolescents, an article that discusses how the influence of conventional methods given by teachers, parents and peers in fulfilling adolescent sex education. Exclusion criteria were opinion article, reviewed articles, including primary research, review articles (systematic review or literature review), and proceeding.

Stage II: Identifying relevant studies: In this scoping review, the researcher used the Google Scholar guidelines and 5 databases, which are PubMed, Science Direct, Wiley, ProQuest and EBSCO. Researchers used the three databases above as a literature study step, so researchers need to determine an article search strategy. Researchers use specific keywords prepared in accordance with the PEOs framework and use the help of Boolean operators such as AND and OR.

Table 2. Keyword

\begin{tabular}{|c|c|c|}
\hline $\mathrm{P}$ & $\mathrm{E}$ & Os \\
\hline $\begin{array}{l}\text { Adolescen OR Teenage OR } \\
\text { Young OR Youth AND }\end{array}$ & $\begin{array}{l}\text { Digital media OR Social media } \\
\text { OR Social Platform OR Social } \\
\text { network OR Internet user OR } \\
\text { Facebook AND konventional } \\
\text { method OR parent OR teacher } \\
\text { OR education OR school OR } \\
\text { family AND }\end{array}$ & $\begin{array}{l}\text { Sex education OR sexual } \\
\text { health information OR Sexual } \\
\text { behavior }\end{array}$ \\
\hline
\end{tabular}

Stage III: Selection of articles: Select articles starting from the title and abstract and do elimination related to the articles that have been selected by doing a full text-reading. The results of elimination using the PRISMA Flowchart diagram. 


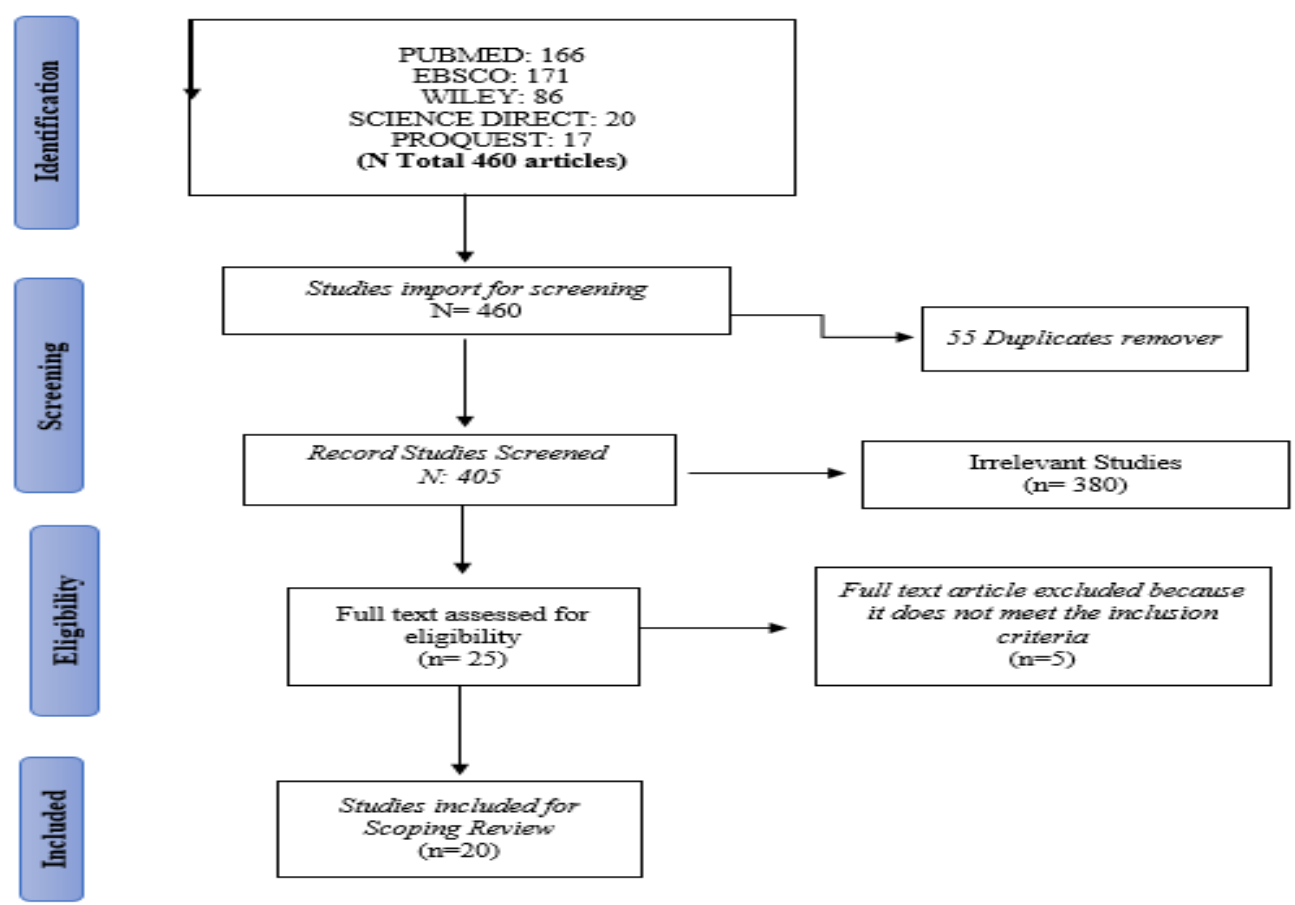

Diagram 1. PRISMA Flowchart

Furthermore, the authors conducted a critical appraisal using a checklist from the Joanna Briggs Institute (JBI).

Stage IV: Mapping the Data (Data Charting): The next step is to do data charting to categorize the results of the articles that have been rated.

Table 3. Article code

\begin{tabular}{cl}
\hline Code & Article/ Author \\
\hline A & $\begin{array}{l}\text { Correlation between parent-adolescent communication and adolescents’ premarital sex } \\
\text { risk/ (Widyatuti, Hafilah Shabrina, \& Yuni Nursasi, 2018) }\end{array}$
\end{tabular}

B Receipt of Sexual Health Information From Parents, Teachers, and Healthcare Providers by Sexually Experienced U.S. Adolescents

(Donaldson, Lindberg, Ellen, \& Marcell, 2013)

C Sexual health education adolescent males who are interested sex with males : an investigation on experience, preferences and needs, (Nelson, Pantalone, \& Carey, 2019)

D Practice and content of sex education Among adolescents in a family setting in Rural southwest nigeria/ (Asekun-Olarinmoye, Dairo, Abodurin, \& Asekun-Olarinmoye, n.d.)

E Sex education and adolescent sexual behavior : do community characteristics matters/ (Kraft, Kulkarni, Hsia, Jamieson, \& Warner, 2012)

F Helping teacher conduct sex education in secondary school in Thailand : overcoming culturally sensitive barriers to sex education/ (Thammaraksa, Powwattana, Lagampan, \& Thaingtham, 2014)

\footnotetext{
$\mathrm{G} \quad$ A right based sexuality education curriculum for adolescent: 1 year outcomes for a cluster / (Rohrbach et al., 2015)
} 
H Family home work and school based sex education: delaying early adolescent sexual behavior/(Grossman, Frye, Charmaraman, \& Erkut, 2013)

I Greek student' knowledge and source of information regarding sex education/ (Matziou et al., 2009)

J Protective Effects of Middle School Comprehensive Sex Education With Family Involvement/ (Grossman, Tracy, Charmaraman, Ceder, \& Erkut, 2014a)

$\mathrm{K} \quad$ Culture and sex education: the acquisition of sexual knowledge for a group of Vietnamese Australian young women/ (Rawson \& Liamputtong, 2010)

L Effects of the culturally-sensitive comprehensive sex education programme among Thai secondary school students/(Thato, Jenkins, \& Dusitsin, 2008)

M Knowledge, attitudes and peer influences related to pregnancy, sexual and reproductive health among adolescents using maternal health services in Ugu, KwaZulu-Natal, South Africa/(Govender, Naidoo, \& Taylor, 2019)

$\mathrm{N} \quad$ Impact of a sex education programme in terms of knowledge, attitudes and sexual behaviour among adolescents in Asturias (Spain)/(García-vázquez, Quintó, \& Agullótomás, 2019)

O Sexual Health and the Internet: Cross-Sectional Study of Online Preferences Among Adolescents/(Von Rosen, Von Rosen, Tinnemann, \& Müller-Riemenschneider, 2017)

$\mathrm{P} \quad$ Use of the Internet as a source for reproductive health information seeking among adolescent girls in secondary schools in Enugu, Nigeria/(Ibegbulam, Akpom, Enem, \& Onyam, 2018)

Q Young men who have sex with men's use of social and sexual media and sex-risk associations: cross-sectional, online survey across four countries/(Lorimer, Flowers, Davis, \& Frankis, 2016)

R Assessing Iranian adolescent girl's needs for sexual and reproductive health information/ (Mosavi et al., 2014)

S The Internet as a Source of Sexual Information in a Sample of Spanish Adolescents: Associations with Sexual Behavior/ (González-ortega, Vicario-molina, Martínez, \& Orgaz, 2015)

T Media's Contribution to Sexual Knowledge, Attitudes, and Behaviors for Adolescents and Young Adults in Three Asian Cities/ (Lou et al., 2012)

Table 4. Data charting

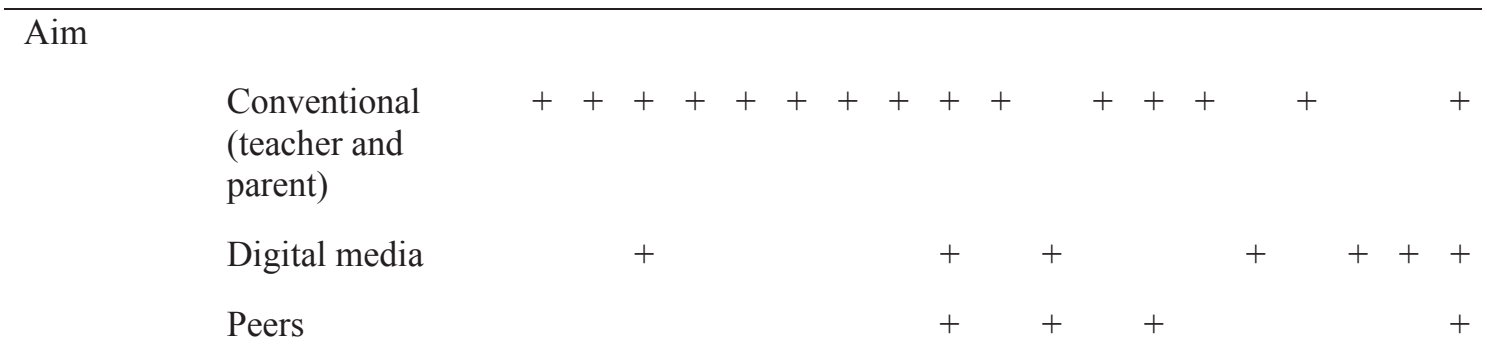

Method 
Type of research

study :

Qualitative

Quantitative

Mix method

Data collection :

Nvivo

SPSS

STATA

FIML

ANOVA

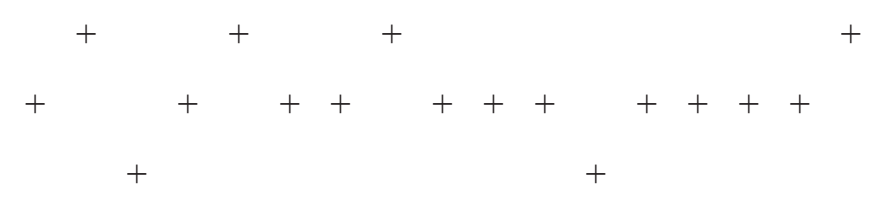

\section{SAS}

Participant $<24$ y.o

Result

$$
\begin{aligned}
& \text { Conventional } \\
& \text { (teacher and } \\
& \text { parent) }
\end{aligned}
$$

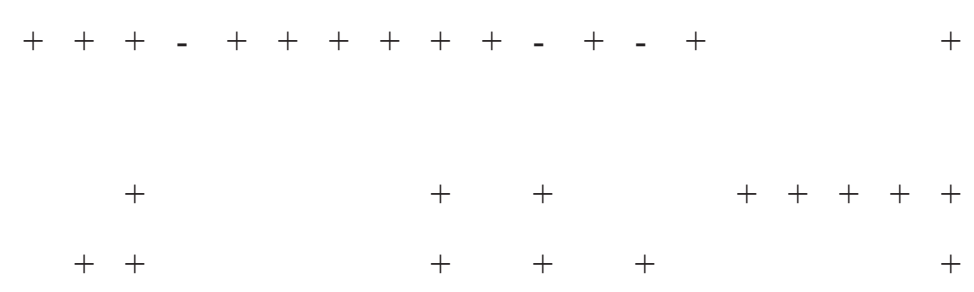

Databased

Sciencedirect

PubMed

Wiley

Ebsco

Proquest

Article code

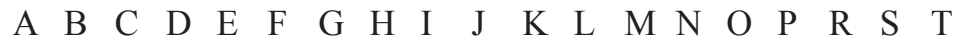

Stage V: Compiling, Summarizing and Reporting the Results: The authors classify the articles with interventions and treatment of sex education for adolescents. The results of the review found several themes that were relevant to the focus review as follows. 
Table 5.Themes

\begin{tabular}{|c|c|c|}
\hline THEMES & SUB THEMES & CODE \\
\hline $\begin{array}{l}\text { Digital media as a source of } \\
\text { information on adolescent } \\
\text { sex education }\end{array}$ & $\begin{array}{l}\text { 1. Easily accessible sites and easy to understand } \\
\text { the material } \\
\text { 2. Inaccurate data } \\
\text { 3. What sexual information do adolescent have } \\
\text { access to } \\
\text { 4. Digital media causes adolescent negative sexual } \\
\text { behavior }\end{array}$ & $\begin{array}{l}\mathrm{O} \\
\mathrm{R} \\
\mathrm{P}\end{array}$ \\
\hline $\begin{array}{l}\text { Conventional methods as a } \\
\text { source of information on } \\
\text { adolescent sex education }\end{array}$ & $\begin{array}{l}\text { 1. Parents as a source of information } \\
\text { 2. The teacher as a source of informationPeers as a } \\
\text { source of information }\end{array}$ & $\begin{array}{l}\text { C,J } \\
\text { B, E,F,G,J } \\
\text { I,M,S }\end{array}$ \\
\hline $\begin{array}{l}\text { Barriers to channeling } \\
\text { information on sex } \\
\text { education to adolescents }\end{array}$ & $\begin{array}{ll}\text { 1. } & \text { Cultural barriers } \\
\text { 2. } & \text { Family barriers } \\
\text { 3. } & \text { Barriers to adolescent lack of knowledge } \\
\text { 4. } & \text { Gender barriers }\end{array}$ & $\begin{array}{l}\mathrm{K} \\
\mathrm{D} \\
\mathrm{Q}, \mathrm{R} \\
\mathrm{B}, \mathrm{T}\end{array}$ \\
\hline $\begin{array}{l}\text { The findings of the study } \\
\text { with the intervention of } \\
\text { adolescent sex education }\end{array}$ & $\begin{array}{l}\text { 1. The existence of a relationship between sex } \\
\text { education and adolescent negative sexual } \\
\text { behavior } \\
\text { 2. The influence of positive family communication } \\
\text { with the prevention of adolescent premarital sex }\end{array}$ & $\begin{array}{l}\mathrm{E}, \mathrm{P}, \mathrm{G}, \mathrm{N} \\
\mathrm{A}, \mathrm{H}, \mathrm{L}\end{array}$ \\
\hline
\end{tabular}

\section{RESULTS AND DISCUSSION}

Based on the results of screening of 20 articles selected from 2008-2019, the data analysts used various methods with 15 articles of quantitative methods and 5 articles of qualitative methods.

\section{The method that has the most role in increasing adolescent sex education knowledge}

Based on the results of screening from 20 articles, it was found that the method using digital media had more contributions in the role of fulfilling adolescent knowledge about sex education information (Ibegbulam et al., 2018). Based on the results of the screening, it was also found that the factors that caused adolescents to prefer access to digital media to fulfill their knowledge of sex education were easy access to the internet, the information obtained was easier to understand and the appearance of attractive websites/sites about sexual health made teenagers prefer digital media for make a source of information about sex education (Von Rosen et al., 2017).

Based on the screening, the results of adolescent knowledge obtained from conventional methods (parents, teachers and peers) also contributed to contributing to adolescent sex education information (Grossman, Tracy, Charmaraman, Ceder, \&Erkut, 2014b). Communication within the family about sexual problems can delay sex among early adolescents (Grossman et al., 2013). Based on the results of the screening article above, it was found that adolescents need accurate information and want this information to come from accurate sources such as family or parents. In accordance with the results of research on the influence of parents on adolescent sex knowledge, it is stated that positive 
communication between parents and adolescents gives positive results to the knowledge of adolescent sex education and vice versa (Widyatuti et al., 2018).

\section{Constraints for adolescents in obtaining sex education information}

Based on the results of the screening of the 20 articles above, it was found that the conventional method had several obstacles in channeling information on knowledge of sex education for adolescents, especially on the conventional method of parents, teachers and peers, which is due to the custom that hangs teenagers to ask parents or teachers about sex education (Rawson \& Liamputtong, 2010). Furthermore, parents also cause obstruction of adolescent education knowledge due to the shame of parents to reveal sex education information to their teenagers. The results of the research on the importance of adolescent sex education stated that many parents feel uncomfortable talking about issues related to sexuality and most adolescents find it difficult when asking something related to sexuality, adolescents also think that when they ask something related to sexuality, the parents they will consider the adolescent to be active in terms of sexuality (Asekun-Olarinmoye et al., nd).

There was also a gender barrier which was a problem in which boys were less informed about sex education than girls. Girls are more informed about sex education than boys. Research testing the effectiveness of sex education programs on the knowledge and attitudes of adolescents gives results where the female group has changes while the male group does not experience significant changes (García-Vázquez, Quintó, \&Agulló-Tomás, 2019). The results of the study describing the extent to which adolescents who have had sexual intercourse receive sexual health information state that there are gaps in the acceptance of sexual health information from parents, teachers and health service providers, adolescents who have had sex and gender differences (Donaldson et al., 2013).

Based on the results of the gender gap screening in the knowledge of adolescent sex education, it was found that male adolescents accessed more porn sites on the internet while female adolescents accessed the internet more to fulfill their sexual education knowledge (Lou et al., 2012). Based on the exposure to the results of the screening article above, it is known that the lack of communication between parents and adolescents causes negative sexual behavior and vice versa. Based on the results of screening the length of internet use and the lack of knowledge of adolescents affecting adolescent sexual behavior, this is reinforced by the results of a study which states that increased opportunities for anal intercourse are related to the length of time using websites and lower levels of knowledge (Lorimer et al., 2016).

From the results of the research screening above, it is found that if communication between parents and adolescents is good, it can delay adolescents from having sex in early adolescence. Parents who do not provide sexual education information and do not exercise inadequate supervision or control of the information media, can put their children at risk of receiving wrong information about sexuality (Notroboto, 2014). In accordance with previous research, the lack of insight into adolescents in sexual education encourages adolescents to find out which adolescents have expressive and explorative characters towards the changes 
that occur in them, so that adolescents will try to get information through several electronic media and the internet (Ernawati, Hapsari, \&Lusmilasari , 2013).

\section{Appropriate research methods in analyzing adolescent sex education problems}

Based on the results of the screening of 20 articles, there were 15 articles with a quantitative research method study with 10 articles of cross-sectional design, 2 articles of quasi experiment, 1 article of RCT, and 1 cohort of articles. Qualitative method with a Focus Group Discussion design with 4 articles and 1 article with a mix method design semi-structure interview and cohort. Thus, it can be concluded to analyze the problem of the best strategy in providing information on adolescent education knowledge, which is using quantitative research methods with cross sectional design.

\section{CONCLUSION}

Based on the results of the discussion above, it can be concluded that the literature gap in this scoping review is the lack of the role of parents and teachers in providing information on sex education to adolescents. Problems in negative adolescent sexual behavior are caused by inaccurate sources such as peers and the internet, adolescents hope to get information on sex education from parents and teachers. Adolescents with knowledge of sex education obtained from internet sources realize that there is inaccurate information from the websites they access but due to lack of information from parents and teachers as well as cultural barriers and low levels of adolescent knowledge, adolescents still use the internet as a source of educational information of sexuality.

Gender is also one of the obstacles in the delivery of sex education to adolescents. In the 20 research articles that have been screened, according to the author, there is no peer participation as key informants or as a triangulation of sources in research because peers can provide information about how they share with each other and what sex education information is often discussed together. The research method that uses the most of the 20 articles is the quantitative method with 15 articles so that the lack of research using qualitative methods to dig deeper information about how adolescents' perceptions of sex education.

\section{REFERENCES}

Arksey, H., \& O’Malley, L. (2005). Scoping studies: Towards a methodological framework. International Journal of Social Research Methodology: Theory and Practice, 8(1), 19-32. https://doi.org/10.1080/1364557032000119616

Asekun-Olarinmoye, E. O., Dairo, M. D., Abodurin, O. L., \& AsekunOlarinmoye, I. O. (n.d.). Practice and content of sex education among adolescents in a family setting in rural southwest Nigeria. International Quarterly of Community Health Education, 32(1), 57-71. https://doi.org/10.2190/IQ.32.1.f

Damarsih, R., Setiyadi, N. A., \& Trisnawati, A. G. (2011). Kajian Perilaku Sex Pranikah Remaja SMA di Surakarta. Jurnal Kesehatan, 4(2), 111-119. 
https://doi.org/1979-7621

Donaldson, A. A., Lindberg, L. D., Ellen, J. M., \& Marcell, A. V. (2013). Receipt of sexual health information from parents, teachers, and healthcare providers by sexually experienced U.S. adolescents. Journal of Adolescent Health, 53(2), 235-240. https://doi.org/10.1016/j.jadohealth.2013.03.017

Ernawati, H., Hapsari, E. D., \& Lusmilasari, L. (2013). Penggunaan Sistem Informasi Berbasis Website Pada Remaja. (10).

García-vázquez, J., Quintó, L., \& Agulló-tomás, E. (2019). Original Article Impact of a sex education programme in terms of knowledge, attitudes and sexual behaviour among adolescents in Asturias. 0(0), 1-9. https://doi.org/10.1177/1757975919873621

García-Vázquez, J., Quintó, L., \& Agulló-Tomás, E. (2019). Impact of a sex education programme in terms of knowledge, attitudes and sexual behaviour among adolescents in Asturias (Spain). Global Health Promotion, 1757975919873621. https://doi.org/10.1177/1757975919873621

González-ortega, E., Vicario-molina, I., Martínez, J. L., \& Orgaz, B. (2015). The Internet as a Source of Sexual Information in a Sample of Spanish Adolescents: Associations with Sexual Behavior. Sexuality Research \& Social Policy, 12(4), 290-300. https://doi.org/http://dx.doi.org/10.1007/s13178-015-0196-7

Govender, D., Naidoo, S., \& Taylor, M. (2019). Knowledge, attitudes and peer influences related to pregnancy, sexual and reproductive health among adolescents using maternal health services in Ugu, KwaZulu-Natal, South Africa. BMC Public Health, 19(1), 1-17. https://doi.org/10.1186/s12889019-7242-y

Grossman, J. M., Frye, A., Charmaraman, L., \& Erkut, S. (2013). Family homework and school-based sex education: Delaying early adolescents' sexual behavior. Journal of School Health, 83(11), 810-817. https://doi.org/10.1111/josh.12098

Grossman, J. M., Tracy, A. J., Charmaraman, L., Ceder, I., \& Erkut, S. (2014a). Protective Effects of Middle School. Journal of School Health, 84(11), 739747.

Grossman, J. M., Tracy, A. J., Charmaraman, L., Ceder, I., \& Erkut, S. (2014b). Protective Effects of Middle School Comprehensive Sex Education With Family Involvement. Journal of School Health, 84(11), 739-747. https://doi.org/10.1111/josh.12199

Ibegbulam, I. J., Akpom, C. C., Enem, F. N., \& Onyam, D. I. (2018). Use of the Internet as a source for reproductive health information seeking among adolescent girls in secondary schools in Enugu, Nigeria. Health Information and Libraries Journal, 35(4), 298-308. https://doi.org/10.1111/hir.12242

Kraft, J. M., Kulkarni, A., Hsia, J., Jamieson, D. J., \& Warner, L. (2012). Sex education and adolescent sexual behavior: Do community characteristics matter? Contraception, 86(3), 276-280. https://doi.org/10.1016/j.contraception.2012.01.004

Lorimer, K., Flowers, P., Davis, M., \& Frankis, J. (2016). Young men who have sex with men's use of social and sexual media and sex-risk associations: 
Cross-sectional, online survey across four countries. Sexually Transmitted Infections, 92(5), 371-376. https://doi.org/10.1136/sextrans-2015-052209

Lou, C., Cheng, Y., Gao, E., Zuo, X., Emerson, M. R., \& Zabin, L. S. (2012). Media's contribution to sexual knowledge, attitudes, and behaviors for adolescents and young adults in Three Asian Cities. Journal of Adolescent Health, 50(3 SUPPL.). https://doi.org/10.1016/j.jadohealth.2011.12.009

Luthfia, A. (2010). M M Co M M Un Ic At Io G. Bl Og Sk Y. Co M M M Co M M Un Ic At Io G. Og Sk.

Matziou, V., Perdikaris, P., Petsios, K., Gymnopoulou, E., Galanis, P., \& Brokalaki, H. (2009). Greek students' knowledge and sources of information regarding sex education. International Nursing Review, 56(3), 354-360. https://doi.org/10.1111/j.1466-7657.2009.00727.x

Mosavi, S. A., Babazadeh, R., Najmabadi, K. M., \& Shariati, M. (2014). Assessing iranian adolescent girls' needs for sexual and reproductive health information. Journal of Adolescent Health, 55(1), 107-113. https://doi.org/10.1016/j.jadohealth.2013.11.029

Nelson, K. M., Pantalone, D. W., \& Carey, M. P. (2019). Sexual Health Education for Adolescent Males Who Are Interested in Sex With Males: An Investigation of Experiences, Preferences, and Needs. Journal of Adolescent Health, 64(1), 36-42. https://doi.org/10.1016/j.jadohealth.2018.07.015

Notroboto, H. (2014). FACTORS AFFECTING SEXUAL BEHAVIOR IN ADOLESCENT PREMARITAL betrothed. Biometrika Dan Kependudukan, $140-147$. Retrieved from http://210.57.222.46/index.php/JBK/article/view/1132

Peterson, J., Pearce, P. F., Ferguson, L. A., \& Langford, C. A. (2016). Understanding scoping reviews: Definition, purpose, and process. Journal of the American Association of Nurse Practitioners, 29(1), 12-16. https://doi.org/10.1002/2327-6924.12380

Pratama, E., Hayati, S., \& Supriatin, E. (2014). Hubungan Pengetahuan Remaja Tentang Pendidikan Seks dengan Perilaku Seks Pranikah pada Remaja di SMA Z Kota Bandung. Jurnal Ilmu Keperawatan, II(2), 149-156. Retrieved from

http://ejournal.bsi.ac.id/assets/files/Jurnal_Keperawatan_Vol._II_No_2_Sept ember_2014_Egy_Pratama,_Sri_Hayati,_Eva_Supriatin_149-156_pdf

Rawson, H. A., \& Liamputtong, P. (2010). Culture and sex education: The acquisition of sexual knowledge for a group of Vietnamese Australian young women. Ethnicity and Health, 15(4), 343-364. https://doi.org/10.1080/13557851003728264

Rohrbach, L. A., Berglas, N. F., Jerman, P., Angulo-Olaiz, F., Chou, C. P., \& Constantine, N. A. (2015). A rights-based sexuality education curriculum for adolescents: 1-year outcomes from a cluster-randomized trial. Journal of Adolescent Health, 57(4), 399-406. https://doi.org/10.1016/j.jadohealth.2015.07.004

Sampieri, R. H. (2009). Systematic Reviews: CRD's guidance for undertaking reviews in health care.

Thammaraksa, P., Powwattana, A., Lagampan, S., \& Thaingtham, W. (2014). 
Helping teachers conduct sex education in secondary schools in Thailand: Overcoming culturally sensitive barriers to sex education. Asian Nursing Research, 8(2), 99-104. https://doi.org/10.1016/j.anr.2014.04.001

Thato, R., Jenkins, R. A., \& Dusitsin, N. (2008). Effects of the culturally-sensitive comprehensive sex education programme among Thai secondary school students. Journal of Advanced Nursing, 62(4), 457-469. https://doi.org/10.1111/j.1365-2648.2008.04609.x

Von Rosen, A. J., Von Rosen, F. T., Tinnemann, P., \& Müller-Riemenschneider, F. (2017). Sexual health and the Internet: Cross-sectional study of online preferences among adolescents. Journal of Medical Internet Research, 19(11), 1-10. https://doi.org/10.2196/jmir.7068

Widyatuti, Hafilah Shabrina, C., \& Yuni Nursasi, A. (2018). Correlation between parent-adolescent communication and adolescents' premarital sex risk. Enfermeria Clinica, 28, 51-54. https://doi.org/10.1016/S11308621(18)30036-6 